\title{
Attitude influence on performance in technical skill acquisition among formal technical trainees
}

\author{
Azodo, Adinife Patrick $\triangle$ \\ Federal University of Agriculture, Abeokuta, Nigeria (azodopat@gmail.com)

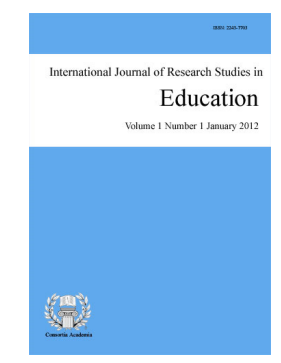

Accepted: 21 August 2014

ISSN: 2243-7703 Online ISSN: 2243-7711

OPEN ACCESS

\section{Abstract}

This cross-sectional study analyzed attitude influence on performance in technical skill involved in a specific trade chosen among all the formal technical trainees of Don Bosco Technical Institute (DBTI), Onitsha, Nigeria. This study was carried out between May and July, 2013. The 24-item questionnaire, designed after critical examination and revision of some related studies and a combination of individual technical projects, sequence of job operation prepared by the students and written tests which cumulatively made up the school academic performance record in technical work were used to assess students' attitude and performance respectively. Analysis of the data showed that majority of the students has positive attitudes towards technical skill involved in technical education. There are also positive relationships between students' attitude in technical skill acquisition and their performance. This was evident from the overall attitude and performance mean scores of 4.3333 and 69.8376 representing $86.67 \%$ and $69.84 \%$ respectively. Pearson correlation coefficient (r) of relationship between attitude and performance in technical skill involved in technical education gave an ' $r$ ' value of 0.366 which was a positive correlation. However, the good performance and knowledge of the usefulness of technical skills in life did not stimulate the students to continue their careers in a related technical profession. This demands serious attention.

Keywords: technical; skill; attitude; performance; students 


\section{Attitude influence on performance in technical skill acquisition among formal technical trainees}

\section{Introduction}

Incessant supply of any nation's workforce for the sustenance of technological and industrial growth of that nation's economy can be achieved through technical education. Technical education offers the trainee both semi-skilled and skilled training required for either construction of new products or modification/maintenance of existing ones (Owolabi, 2003). This evolved from the non-formal apprenticeship programme to a more sophisticated formal training in skills acquisition (Arowolo, 2010).

The overriding requirement for practical is the ability of the learner to be able to do the job rather than only talk about it (Odu, 2011). According to Chauhan (1983), the job and competence of craftsmen are measured by what he/she can do as against how well he/she can describe what he/she can do. The worth of an individual to society grows out of contribution of his/her skills, knowledge and applied productive capacity to tasks that need to be completed rather than out of artificial status connotation attached to some glamorous jobs (Okorie, 2001). In this regard, technical education is a suitable type of education that is capable of responding to economic and labour force changes in the society (Dasmani, 2011).

To maximize the usefulness of technical education, the trainee, staff situation, funding, adequate training facilities and social services must be effectively engaged and exploited (Olunwa, 2007; Sahu, 2008). While staff situation, funding, adequate training facilities and social services may serve as input variables, trainee's performance represents the aftermath of nominal engagement and utilization of these input variables. Although there is no reliable statistics on manpower demands in technical manpower development in the country (Ekunke, 2008), the projection data available showed that there has been acute shortage on manpower required for self-reliance and national development in the nation (Olaitan, 1996). More so, there has been technical skills gap between the students of technical/vocational education and the industry in the country (Idris \& Rajuddin, 2012).

Researches have demonstrated that ineffective and inefficient training of the students reflects in the quality of graduates produced (Dasmani, 2011). Ozoro (1990) asserted that lack of required competence and resourceful skills of technical personnel marks a lot of supposedly unemployed technical personnel in the nation. This makes the student factor the major focus in this study.

\subsection{Stages of development in technical knowledge}

Students gain better understanding and improve their ability to utilize their skills through cognitive, associative and autonomous stages in technical skill acquisition (Anderson, 1995; Gibson, 2011). At the cognitive stage which is the first stage of skill acquisition, the teacher exposes the students to the basic knowledge of handling tools and equipment in execution of a particular task. During this stage the learner develops an in-depth understanding of the skill to be acquired. The second stage of skill acquisition is the associative stage. This is the period of putting into practice those things that has been learnt through a series of project works. While autonomous stage is the final stage where the student accurately execute and finish a project or task unaided. Improvement on what has been learnt by constant involvement in technical works refines what the students acquire on daily basis (Gibson, 2011).

\subsection{Status quo of Technical education in the society}

In spite of the importance and relevance of technical education in training and production of highly skilled, competent and self-reliant middle level manpower for the nation's economic and technological growth, technical 
Attitude influence on performance in technical skill acquisition among formal technical trainees

education has suffered society apathy since inception which is still not different from what we have today (Ozoro, 1982; Odu, 2011). According to Okafor (2011), technical education is a very vital educational sector that is neglected yet it is an inevitable sector that must be embraced in order to make significant progress in terms of national development and job creation. Technical education has long been regarded as education for the poor, mediocre and the undermined (Adesina, 1982; Olaitan, 1996; Odu, 2011; Azubuike, 2011). This gross misconception of the nature and purpose of technical education was postulated as being predominant in developing countries like Nigeria [Adesina (as cited in Lawal, 2012)].

Okocha's (2009) study established that although parents recognize the employment value inherent in technical related courses found in technical/ vocational education, they are still prepared to accept the superiority of socially prestigious and white-collar professions over technical related occupations. Most researches in this area of study explained and emphasized the importance, challenges and ways to improve and revitalize technical education (Ezekiel \& Usoro, 2009, Olaitan, 1996, Ozoro, 1982, Ekunke, 2008, Mbata, 2000, Al-Nasra, 2013, Sahu, 2008, Ojimba, 2012). Sahu (2008) classified factors that affect the effectiveness of technical education under seven broad categories as; administration, infrastructure, teaching effectiveness, students, interaction with industry and society, extra-curricular activities, and research and development. All these factors play crucial role in imparting of specific job-relevant skills for the nation's economic and labour force changes found in technical/vocational education. There are few found literatures that considered students factors in technical education settings (Azubuike, 2011; Lawal, 2012). While, Lawal's (2012), study observed that students in rural area have higher disposition towards technical education than their counterparts in the urban settings. However in both cases the study revealed that there was disproportionate relationship between students' performance and their interest in technical education. Major influential factors affecting the attitude of students towards technical/vocational subjects observed by Azubuike (2011) were interest, gender, socio-economic status, qualification of teachers/instructors and guidance counsellors.

\subsection{Attitude and learning}

People are attracted or repelled to something by their views concerning that thing. What determines whether one will be attracted, get the best and make good representation of an experience is attitude. Attitude is an individual attribute can be developed, influenced and changed over time. Researches have shown that attitude plays a very vital role in learning processes (Joyce \& Farenga, 2000; Osborne, Simon, \& Collins, 2003; Altınok, 2004; Sabellah, 2010; Anwer, 2012). The learning ability of an individual can be increased by improving such individual's attitude (Depaolo \& Mclaren, 2006). Attitude arouses student's interest, stirs participation and consequently achievement (Anwer, 2012). According to Mwamwenda (1995) students' performance in a particular subject is determined by their attitudes not ability to study. A number of studies on students' attitude and academic achievement correlation found in literatures showed positive relationship (Aremu, 1998; Cheung 2009; Njuguna (as cited in Sabellah, 2010); Rana 2002; Papanastasiou \& Zembylas, 2004; Fraser \& Fisher (as cited in Fraser \& Tobin, 1998); Myint \& Goh, 2001; Chui-Seng, 2004; Mucherah, 2008; Akpınar, Yıldız, Tatar, \& Ergin, 2009).

These studies elicited information such as academic workload, teacher qualification, classroom environments, students' gender, socio-economic status as factors that influences students attitude and hence performance (Orodho (as cited in Sabellah, 2010); Ndonga (as cited in Sabellah, 2010); Otami, 2012; Fraser \& Fisher (as cited in Fraser \& Tobin, 1998); Myint \& Goh, 2001; Chui-Seng, 2004; Mucherah, 2008; Neathery, 1997). Both positive and negative attitude have strong impact on the success of a subject learnt (Mordi, 1991). Negative attitude developed by an individual towards a subject reduces the chances of good performance of such individual in that area (Sabellah, 2010). Negative attitude could make a learner actively resist instructions which according to Haimowitz (as cited in Mbugua, Kibet, Muthaa, \& Nkonke, 2012) causes most failure in schools. Depaolo \& Mclaren (2006) observed a strong tie between negative attitudes and poor performance in examination. Similarly, Maundu (as cited in Sabellah, 2010) observed that poor achievement may lead to development of poor attitude towards learning. Conversely, good performance breeds positive interest in a 
particular subject (Aremu, 1998). Understanding of students' attitude is important in supporting their achievement and interest towards a particular discipline (Gul \& Arshad, 2012).

\section{Purpose of the Study}

In every chosen career, there is a required minimum level of training or preparation an individual has to pass through so as to enable such an individual obtain and retain relevance in that chosen career (Odu, 2007). Every occupation can benefit both the trainee and his/her society if the minimum level of training or preparations needed in that occupation is attained by the trainee, (Odu, 2007). In this view, this study is concerned with the attitude influence on performance in technical skill involved in a specific trade chosen among formal technical trainees.

\subsection{Significance of the study}

With the knowledge of the society despise of technical education and the peculiarity of obtaining formal technical training under a secondary education like-setting by senior secondary school graduates for a training duration of two years at DBTI, Onitsha incited the researcher to carry out this study. This study was designed to elicit the various factors that influence students' attitude and performance in technical skill acquisition. It therefore presents a prototype for controlling poor performance in formal technical trainees and highlights the factors that propagate students' positive attitude towards technical work. Moreover the findings in this study will add to the knowledge base of effects of attitude towards academic achievement which will be useful in different disciplines in academic field especially in technical education.

\section{Method}

\subsection{Participants}

This cross-sectional study of all the technical trainees of DBTI, Onitsha, Nigeria was carried out between May and July, 2013. The entire year one and year two trainees of electrical and mechanical engineering departments of the school were included. Those who decline participation for whatever reason were not included in this study. A total of 117 trainees participated in the study. The aim of the study was explained to the concerned officials and the trainees after which informed consent was obtained from the participants. Participation in this study was voluntary and no incentive was offered.

Critical examination and revision of some studies in technical education and on relationship between attitude and performance in different subject areas (Gul \& Arshad, 2012; Sabellah, 2010; Lawal, 2012) helped to generate the items on the questionnaire for the purpose of the study. The 24-item questionnaire used for this study assessed demography and students attitude factors. The attitude scale was a 5-point Likert scale (strongly agrees, agree, undecided, disagree, and strongly disagree). An appropriate scoring scheme was associated with each of the five possible responses, e.g. strongly agree $=5$, agree $=4$, undecided $=3$, disagree $=2$, strongly disagree $=1$. The scaling mean point was computed to aid decisions to be made on each of the items. Therefore, for each item, the responses and the overall attitude score towards technical works for each student were categorized as "agree", if the score was in the range of 3.5 and above, "undecided", if in the range of 2.6-3.4 and "disagree" if 2.5 and below.

\subsection{Research process}

The terminology "technical work" used in this research covers all the technical skills in the various specialized trade in the school. Students were assessed through a combination of individual technical projects, sequence of job operation prepared by the students and written tests. These cumulatively make up the academic performance record in the school. The researcher with the assistance of the workshop instructors administered 
Attitude influence on performance in technical skill acquisition among formal technical trainees

the questionnaire to the students in the last technical works class for the terms and collected the same day.

\subsection{Data analysis}

The statistical analysis was done to determine the frequency distribution, percentage ratio, mean and standard deviation for each of the students' response to each of the variables on the questionnaire. Pearson correlation coefficient ' $r$ ' was used to find out attitude and performance relationship in technical work was tested at alpha level 0.05 or $95 \%$ confidence level. The data were analyzed using Statistical Package for Social Science (SPSS) version 16.0. The results obtained were arranged in tables.

\subsection{Validation and reliability of instrument}

The questionnaire used in this study was scrutinized by different professionals in statistics and technical education. The questionnaire was repeatedly edited and modified following the suggestions stated by these professionals before the final copy was ready. In addition the questionnaire was pre-tested before the actual data collection. In other not to demotivate the respondents and still achieve the reliability the items on the questionnaire was limited to 24 items. This falls within the accepted questionnaire item range recommended by Nunnally (as cited in Al-sa'd, 2007) for reliability of a study. The students were also observed and monitored as they perform each operation unaided.

\section{Results and Discussions}

\subsection{Demographic characteristics of participants}

Of the 130 questionnaires distributed to the students, nine were not completed and four were not returned giving the response rate of $117(90 \%) .50 .4 \%$ of the correspondents were electrical and $49.6 \%$ were mechanical engineering students. Majority of the correspondents were male 111(94.9\%) and 6(5.1\%) were female. 69(59.0\%) and $48(41.0 \%)$ of the correspondents were in year one and two respectively.

\subsection{Technical students' attitude towards technical work}

The mean and standard deviation of the responses to each of 21 items of the questionnaire designed to measure students' attitude towards technical skill acquisition from a total of 117 students who participated in the study is shown below (Table 2). Analysis of the data showed that majority of the students has positive attitudes toward technical skill involved technical education. The responses also indicated that the item 15 in the questionnaire which states that "Technical works are useful in life" has the highest mean score of 4.7436, while item 9 in the questionnaire which states that "I hate technical work" gave the lowest mean score of 1.9573. This gave a mean difference of 2.7863 .

The analyzed data revealed that most students enjoy technical work. Technical skills in technical/vocational education is practical application-oriented. Simply put, it is more of hands-on learning process than work-shadowing and theory. Generally, it has little to do with memorizing one thing or the other. This "non-brain tasking" seemly teaching approach adopted in technical skill learning process makes the trainees enjoy technical work hence positive attitude towards the subject. The students disagree that the whole exercise of applying the technical skill in technical work is difficult for them to understand. Majority of the students disagree that the technical works periods are boring; as such they see nothing wrong with the duration of technical skill acquisition period. Correspondingly most students disagree that no matter how hard they try they cannot understand technical work.

From the responses to item 20 in the questionnaire which assessed students' likeness for technical works tests, assignments and homework, it revealed that most students could not ascertain their stand (undecided) on 
Azodo, A. P.

assessment exercises involved in technical work. Different task demands different creativity and problem-solving ability from the trainee. If learners are assigned to difficult tasks beyond their abilities, they may develop negative attitude towards the subject and vice versa (Sabellah, 2010).

\section{Table 1}

Technical students' attitude towards technical work

\begin{tabular}{lccl}
\hline \multicolumn{1}{c}{ Characteristics } & Mean & SD & Interpretations \\
\hline Enjoy technical works & 4.4444 & 0.90444 & Agree \\
The task in technical works are easy & 3.2051 & 1.26313 & Undecided \\
Self-competence in handling technical works & 3.1795 & 1.32363 & Undecided \\
Easy access to instructor in face of challenges & 3.4359 & 1.41046 & Agree \\
Frequency of idleness & 2.4530 & 1.35504 & Disagree \\
Understand meaning of concepts and terms used in technical works & 4.1538 & 0.98799 & Agree \\
Happy with my results in technical works & 4.3333 & 1.00000 & Agree \\
Studying technical works more than any other subject & 4.3248 & 1.03248 & Agree \\
I hate technical skill acquisition subjects & 1.6325 & 1.03888 & Disagree \\
Feeling about technical work & 3.7094 & 1.23916 & Agree \\
Technicality in technical work is difficult to understand & 2.3333 & 1.46217 & Disagree \\
I cannot understand technical work & 1.9573 & 1.00338 & Disagree \\
I try to do the very best in technical skill acquisition subjects & 4.5640 & 0.95940 & Agree \\
I can do without technical works & 2.8034 & 1.58788 & Undecided \\
Technical works are useful in life & 4.7436 & 0.77852 & Agree \\
Continue career in technical related profession & 2.3248 & 1.41926 & Disagree \\
Technical works periods are boring & 2.1880 & 1.19577 & Disagree \\
Desire to do better in technical skill acquisition subjects & 4.6496 & 0.87411 & Agree \\
Feeling about technical works assessment and training tasks & 3.3333 & 1.28654 & Undecided \\
Like technical works tests, assignments and homework & 2.0000 & 1.10641 & Disagree \\
Feel positive about telling friends where you school & 4.1282 & 1.17105 & Agree \\
\hline
\end{tabular}

The undeceive attitude towards the technical skill assessment may be as a result of some technical aspect that are difficult while others are not. However majority of the students desire to do better after being evaluated on technical skill acquired in the school. Their efforts and positive attitude towards improvement and advancement on their various levels of performances is seem in their study of technical skill acquisition subjects more than other subjects hence they try to do their very best so as to perform better in the subjects. In addition the analysis of data, also show that majority of the students are not positive about being idle in technical skill acquisition classes. This explicitly demonstrates their knowledge and awareness that technical skills are useful in life hence positive attitude.

The application of concepts and terms used in technical skill is repetitive in nature as they are involved in the preparation of the all sequence of job operation in the workshop, this includes the various stages in the work process, the materials, tools/equipment that should be engaged and techniques required. The positive mean score of 4.1538 obtained on this item in the questionnaire showed that most of the students understood the concepts and terms used in technical works.

Technical/vocational education as stated earlier in this study is application-oriented, thus it requires intimate teacher-student relationships as well as teaching approach that will make the student not to see the subject as something abstract or difficult to understand. Once a subject is perceived as being difficult, it instigates negative attitude in the students. Depaolo \& Mclaren (2006) discovered that students' attitude improve over their study within the environment created by the instructors alongside the performance. The supportive attitude of the 
Attitude influence on performance in technical skill acquisition among formal technical trainees

teacher/instructor is believed to influence and create positive attitude in the students (Kususanto, Fui, \& Lan, 2012; George, 2000; Papanastasiou, 2002; George, 2003). This was in agreement with the result in this study. In the face of challenges during work execution, the students get easy access and timely intervention of their instructors' for clarification and continuation of the technical work process. This makes their feeling towards technical work positive but distorts their stand on easiness of task in technical work and their self confidence in handling technical works. In the same vain, the students were not certain about their feelings towards technical skill acquisition. The students though they are positive about telling friends where they school, they are not positively certain that they will take technical related careers in life. This make them repudiate that they cannot do without technical work. This observation is not different from what is obtainable in the society. This apathy to vocational/technical education cut across the parents, the wards and the society at large. This in turn leads to the development of a negative attitude towards taking up professional career in technical oriented courses.

\subsection{Attitude influence on performance in Technical skill acquisition}

According to Sabellah (2010) and Aremu (1998) good performance does not only make students who perform well in a particular subject develop a positive interest towards the subject but also motivates them to work hard that area. In contrast, poor performance has a tendency to retract the learner's efforts from studying the subject. It was found in this study that the students are happy about their performance in technical works. This implies that they have positive attitude towards the subject. Positive attitude has been found in studies to have consequential link with performance (Burrow, 1978; Otami, 2012; Myint \& Goh, 2001; Chui-Seng, 2004; Mucherah, 2008). The findings in this study agree with the above studies as it revealed that there were positive relationships between students' attitude in technical skill acquisition and their performance. This is evident from the attitude and performance mean scores of 4.3333 and 69.8376 representing $86.67 \%$ and $69.84 \%$ respectively. These gave an ' $r$ ' value of 0.366 which was a positive correlation implying that attitude of the students stirs up their interest towards technical skill and their tendency to grab much from what was taught (Table 3). This consequently affected their performance positively.

\section{Table 2}

Correlation between attitude and performance in technical works

\begin{tabular}{llll}
\hline No of students $(\mathrm{N})$ & Attitude & Performance & Pearson Correlation (r) \\
\hline 117 & 4.3333 & 66.0769 & $.366^{* *}$ \\
\hline Note. ${ }^{* *}$ Correlation is significant at the 0.01 level (2-tailed) & &
\end{tabular}

\section{Conclusion}

Technical skill in technical education train and equip trainees with the necessary skills required in occupations like engineering manufacturing and industrial professions. This study revealed that attitude plays a very vital role in the production of highly skilled, competent and self-reliant middle level manpower capable of responding to economic and labour force changes in the society. The various attitude factors analyzed showed that attitude could make or mar the outcome of students learning process. The positive influence of attitude on performance in technical skill acquisition could be traced to the adoption of practical approach in teaching the students which allowed the students to handle the tools/equipment by themselves, quick intervention of the instructors in the face of challenges and continuous engagement of tools/equipment which made them conversant with the concepts and the terms used in technical works. However the good performance and knowledge of the usefulness of technical works did not stimulate the students to continue their careers in related profession. This indicates that society apathy towards technical education has strong influence on the students. It is therefore recommended that drastic measures should be taken to improve the society view towards technical education. 


\section{References}

Adesina, S. (1982). Planning and educational development in Nigeria. Ibadan: Board Publications Limited. Akpınar, E., Yıldız, E., Tatar, N., \& Ergin, Ö. (2009). Students' attitudes toward science and technology: An investigation of gender, grade level, and academic achievement. Procedia-Social and Behavioral Sciences, 1(1), 2804-2808. http://dx.doi.org/10.1016/j.sbspro.2009.01.498

Al-Nasra, M. (2013). Improved teaching techniques in technical education. Journal of Studies in Education, 3(3), 49-56. http://dx.doi.org/10.5296/jse.v3i3.3729

Al-sa'd, A. (2007). Evaluation of students' attitudes towards vocational education in Jordan. Malmö Studies in Educational Sciences, 32, 1-185.

Altınok, H. (2004). Öğretmenlerinin fen öğretimine yönelik tutumlarına ilişkin öğrenci algıları ve öğrencilerin fen bilgisi dersine yönelik tutum ve güdüleri. Hacettepe Üniversitesi Eğitim Fakültesi Dergisi, 26, 1-8.

Anderson, J. R. (1995). Learning and Memory: An Integrated Approach. New York: John Wiley \& Sons, Inc.

Anwer, M., Iqbal, H. M., \& Harrison, C. (2012). Students' attitude towards science: a case of Pakistan. Pakistan Journal of Social and Clinical Psychology, 10(1), 3-9

Aremu, A. (1998). Motivating learners for more achievement in mathematics. Journal of applied Psychology, 4(1), 27-34.

Arowolo, A, A. (2010). Historical factors that influences curriculum development in industrial technical education in Nigeria. Unpublished masteral thesis, University of Nigeria, Nsukka.

Azubuike, O. C. (2011). Influential factors affecting the attitude of students towards vocational/technical subjects in secondary schools in south eastern Nigeria. Journal of Educational and Social Research, 1(2), 49-56.

Burrow, E. D. (1978). The relationship among secondary science students locus of control, views of the tentativeness of science, attitudes, perceptions of teaching strategies and achievement. Dissertation Abstract International 39(7), 2165.

Chauhan, S. S. (1983). Innovation in teaching learning process. New Delhi: VICAS Publishing House, PVT Ltd.

Cheung, D. (2009). Developing a scale to measure students' attitude towards chemistry lessons. International Journal of Science Education, 31(16), 2185-2203. http://dx.doi.org/10.1080/09500690802189799

Chui-Seng, Y. B. (2004). Secondary science students' perceptions of their learning environment and its association with achievement in biology. Learning Environment Research, 7, 134-146.

Dasmani, A. (2011). Challenges facing technical institute graduates in practical skills acquisition in the upper east region of Ghana. Asia-Pacific Journal of Cooperative Education, 12(2), 67-77.

Depaolo, C., \& Mclaren, C. H. (2006). The relationship between attitudes and performance in business calculus. INFORMS Transactions on Education, 6(2), 8-22. http://dx.doi.org/10.1287/ited.6.2.8

Ekunke, C. U. (2008). Strategies for improving manpower production in vocational technical education in Nigeria global. Journal of Educational Research, 7(1\&2), 31-35.

Ezekiel, O. A., \& Usoroh, E. B. (2009). Recreating vocational education for self-reliance and productivity. Journal Qualitative Education, 5(3), 89-94.

Fraser, B. J., \& Tobin K. G. (1998). International Handbook of Science Education. Netherlands: Kluwer Academic Publishers. http://dx.doi.org/10.1007/978-94-011-4940-2

George, R. (2000). Measuring change in students' attitudes towards science over time: an application of latent variable growth modeling. Journal of Science Education and Technology, 9(3), 217-225. http://dx.doi.org/10.1023/A:1009491500456

George, R. (2003). Growth in students' attitudes about the utility of science over the middle and high school years: evidence from the longitudinal study of American youth. Journal of Science Education and Technology, 12(4), 439-448. http://dx.doi.org/10.1023/B:JOST.0000006303.63545.0f

Gibson, A. (2011). Stages of skill acquisition. Retrieved September 13, 2013, from http://www.prezi.com/hi3g_n1kkuwu/stages-of-acquisition/

Gul, N. K., \& Arshad. A. (2012). Higher secondary school students' attitude towards chemistry. Asian Social Science, 8(6), 165-169.

Idris, A., \& Rajuddin M. R. (2012). The influence of teaching approaches among technical and vocational 
Attitude influence on performance in technical skill acquisition among formal technical trainees education teachers towards acquisition of technical skills in Kano State-Nigeria. Journal of Education and Practice, 3(16), 160-165.

Joyce, B. A., \& Farenga, S. J. (2000). Young girls in science: Academic ability, perceptions, and future participation in science. Roper Review, 22(4), 261-262. http://dx.doi.org/10.1080/02783190009554048

Kususanto, P., Fui, C. S., \& Lan, L. H. (2012). Teachers' expectancy and students' attitude towards science. Journal of Education and Learning. 6(2) 87-98.

Lawal B. O. (2012). Attitude of students towards technical education in Osun state. Asian social science, 8(3), 208-217. http://dx.doi.org/10.5539/ass.v8n3p208

Mbata, A. (2000). Towards a more effective manpower, training and development in technical education in Nigeria. Journal of Technical Education Review, 2(2), 20-31.

Mbugua, Z. k., Kibet, K., Muthaa, G. M., \& Nkonke G. R. (2012). Factors contributing to students' poor performance in mathematics at Kenya certificate of secondary education in Kenya: A case of Baringo country, Kenya. American International Journal of Contemporary Research, 2(6), 87-91.

Mordi, C. (1991). Factors associated with pupils' attitude towards science in Nigeria primary schools. Research in Science and Technology Education, 9(1), 39-49. http://dx.doi.org/10.1080/0263514910090104

Mucherah, W. (2008). Classroom climate and students, goal structure in high school biology classrooms in Kenya. Learning Environment Research, 11, 63-81. http://dx.doi.org/10.1007/s10984-007-9036-x

Mwamwenda, T. S. (1995). Educational psychology: An African perspective. London: Heinemann Bulterworth Publishers Ltd.

Myint, S. K., \& Goh, S. C. (2001). Investigation of tertiary classroom learning environment in Singapore. Paper Presented at the International Educational Conference, Australian Association for Educational Research (AARE), University of Notre Dame, Fremantle, Western Australia.

Neathery, M. F. (1997). Elementary and secondary students' perceptions toward science and the correlation with gender, ethnicity, ability, grade, and science achievement. Electronic Journal of Science Education 2(1), 2-11.

Odu, K. O. (2007). Causes and control of wastage in vocational/technical institutions. Journal Educational Research and Policy, 2(4), 35-40

Odu, O. K. (2011). Philosophical and sociological overview of vocational and technical Education in Nigeria. American Eurasian Journal of Scientific Research, 6(1), 52-57.

Ojimba, D. P. (2012). Vocational and technical education in Nigeria: issues, problems and prospects' dimensions (IPP). Journal of Educational and Social Research, 2 (9)

Okafor, E. C. (2011). The role of vocational and technical education in manpower development and job creation in Nigeria. Journal of Research and Development, 2(1), 152-159.

Okorie, J. U. (2001). Vocational industrial education league of researchers in Nigeria, Bauchi, Nigeria.

Olaitan S. O. 1996. Vocational education in Nigeria and manpower development. Unpublished manuscript, University of Nigeria, Nsukka.

Olunwa, O.T. (2007). Constraints to the implementation of universal basic education. Journal of Education Foundations 4, 153-158.

Osborne, J., Simon, S., \& Collins, S. (2003). Attitude towards science: A review of the literature and its implications. International Journal of Science Education, 25(9), 1049-1079. http://dx.doi.org/10.1080/0950069032000032199

Otami, D. C., Ampiah, J. G. \& Anthony-Krueger, C. (2012). Factors influencing elective science students' perception of their biology classroom environment in low and high academic achieving schools in the central region of Ghana. International Journal of Research Studies in Education, 1(1), 35-46. http://dx.doi.org/10.5861/ijrse.2012.v1i1.3

Owolabi, H. O. (2003). Technical and vocational education in Nigeria. In J. O. Abiri (Ed.), Perspective on history of education in Nigeria (pp. 107-116). Ibadan: Emola-Jay Communications International.

Ozoro, O. (1982). Problem areas in Nigeria education: The school curriculum-technology in secondary schools. Nigerian Journal of Technical Education, 1(2), 5-20.

Ozoro, V. B., (1990). Principles of Co-operative Vocational Education. New York: Heinemann 
Azodo, A. P.

Papanastasiou, C. (2002). School, teaching and family influence on student attitudes towards science, based on the TIMMS data for Cyprus. Studies in Educational Evaluation, 28, 71-86.

http://dx.doi.org/10.1016/S0191-491X(02)00013-5

Papanastasiou, E. C., \& Zembylas, M. (2004). The effect of attitudes on science achievement: A study conducted among high school pupils in Cyprus. International Review of Education, 48(6), 469-484. http://dx.doi.org/10.1023/A:1021334424571

Rana, R. A. (2002). Effect of parents, socioeconomic status, students, self-concept and gender on science-related attitudes and achievement. Unpublished doctoral thesis, University of the Punjab, Lahore.

Sabellah, M. (2010). The Relationship between attitude and academic performance in chemistry among secondary school students. A case of central Kisii district, Kenya. Unpublished Masteral thesis, Moi University Eldoret, Kenya.

Sahu, A. R., Shrivastava, R. L., \& Shrivastava, R. R. (2008). Key factors affecting the effectiveness of technical education- An Indian perspective. Proceedings of the World Congress on Engineering, London, U.K. 